\title{
『政治の司法化と民主化』
}

晃洋書房 2017年 iv +280 頁

\section{今泉 慎也}

本書は，現代の東南アジアをはじめとする世界の国々において顕在化している「政 治の司法化」（judicialization of politics）と民主化との関係について，東南アジア諸国 を中心とする実証研究にもとづき論じたものである。本書のなかで引用されるドレッ セルの定義によれば，司法化とは，狭義には，「判事による違憲審査が政策に寄与し たり影響を与えたりする方法」，広義には「政治や社会において司法過程や裁判所の 判決の存在感が増すこと」とされる (本書 1 頁)。

「東南アジアでは，政治の司法化が着実に進んでおり，司法機関が従来よりも積極 的になっている」(13頁)。その背景には，1980年代後半から民主化が進展するなかで， 伝統的な議会主権から立憲主義による権力抑制を重視する考え方への変化がある。

つまり，憲法の最高法規性を前提に，議会が制定する立法や行政機関の行為などの 違憲審査を行う憲法裁判所の新設，最高裁判所など司法機関の司法審査権限の拡大 が進展したことがある。裁判所に関する政治的観点からの分析は遅れており，それを 補うところに本書の狙いがある。

本書における基本的な問いは，司法化が民主化にどのような影響を与えているか, というものである。司法化は，立憲主義のひとつの発現形態であつて，それゆえに立 憲主義と民主主義との関係，さらには立憲主義を支える法の支配と民主主義との関係 をどう捉えるかという理論的問題と深く結びついている。司法化を肯定的に捉える論 者が陷りがちな司法の無謬ないしは性善説的な捉え方に対してもつと懐疑的であるべ きとする。さらに，本書における興味深い論点のひとつは，「司法化が民主主義に対 してなしうる寄与は，民主化の段階によって違い」があるということである。「新興 民主主義諸国では，立憲主義で保護される少数派は政治的な弱者ではなく，民主化 以前の旧体制で特権を享受してきた人びとであること」が多く，司法化は，「少数派 の圧政を助けて，民主主義体制への移行を妨害することになりかねない」と論じられ 


\section{る $(13$ 頁 $)$ 。}

分析の対象としては，タイ，フィリピン，インドネシア，マレーシア，ミャンマー の東南アジア 5 か国に加えて，比較のためにインド，エジプト，ロシア，韓国の 4 か 国を取り上げる。各国の比較の基礎となっているのが，「司法による政治的関与」と 「司法の独立」を軸とするマトリクスにもとづく「司法政治」の 4 類型である（ 3 頁）。 すなわち，1）「司法の政治化」(司法の独立が小さく，政治関与が大きい：夕イ）, 2 ）「司法の積極主義」(独立大，関与大；フィリピン，インドネシア，３）「司法の 沈尔」(独立小，関与小：カンボジア），4）「司法の自制」(独立大，関与小：マレー シア）である (なお，ミャンマーは13頁図 1 には入っていない)。以下では東南アジ ア諸国に限って本書の考察を紹介しよう。

「司法の政治化」に該当するのがタイである。選挙で繰り返し勝利するタックシン 支持派とその退陣を図るエリート層との権力闘争のなかで，司法は2006年以降，対立 の一方の当事者にあからさまに荷担してきた。2006年と2014年の 2 度にわたって, 説 得力の乏しい理由で総選挙に無効判決を下す一方，軍事クーデ夕を追認する役割を 果たしてきた。第 1 章「タイにおける司法化と君主制」（玉田芳史）は，「憲法裁判 所を中心とする司法が，ここ10年間果たしてきた役割は，多数決民主主義に批判的な エリートに都合よく起草された憲法を怨意的に解釈することで，エリートを守ること であった」(20頁) と論じる。そして，司法化の背景には「司法府と君主制の特殊な 関係がある」が，「君主制のための司法化は，立憲主義も多数決民主主義も台無しに しており，君主制の護持に寄与していない」(21頁) とする。

「司法の積極主義」に該当するのが，フィリピンとインドネシアである。1986年に マルコス政権を打倒し民主化が始まったフィリピンでは，最高裁判所が大統領に不利 な判決を下すことが何度もあり，政治の司法化が進んでいる。第 2 章「弱い司法の 「独立性」：フィリピンの最高裁判所と大統領」（日下渉）は，各政権と最高裁判所の 関係を検討する。「民主化後の大統領は，人事を通じて影響力を行使しょうとしたが， 誰も最高裁判所を飼いならせなかった」（64頁）とする。最高裁判所の独立性は，制 度的条件ないしは「立憲主義に立脚していたからというよりも，むしろ多様なアク夕 一の介入によって政治化された結果」であり，「様々な政治勢力からの介入や判事の 政治アクター化に対して「弱い」がゆえに，大統領に対する「強さ」を発揮している という逆説」(65頁) を見出すことができると結論する。

次に，1998年のスハルト体制崩壊後，民主化が進んでいるインドネシアでは，「司 法化が民主主義体制の定着を大いに助けている」(14頁)。2003年に設立された憲法 裁判所が民主政治に不可欠な選挙に最終的な裁定を下寸役割を担っている。第 3 章 「インドネシア憲法裁判所の生存戦略と政治参加」（相沢伸広）は，「制度と実績，民 
主制の強化と憲法裁の制度的強化が相互補完的に進むという好循環」が生じている ことを示し，それがうまく回り続けるには，「その好循環に利益を見出す裁判官個人 のインセンティブが必要」（88頁）であり，「民主主義と法治主義に相互補完的な利益 を見出せる政治的野心をもった憲法裁判事の存在が有効な触媒として機能した」(89 頁）と指摘する。また，第 4 章「インドネシアにおける政治の司法化，そのための脱 司法化：污職撲滅委員会を事例に」(岡本正明) は，司法化が民主化に寄与する事例 としてインドネシアの污職撲滅委員会（KPK）が，国会議員等の污職・不正の摘発・ 訴追の実績と中立性のゆえにもっとも信頼される国家機関となっており,「インドネ シアにおける法の支配，民主主義の質を高める上で重要な役割」(114頁) を果たして きた，と指摘する。しかしながら，不満を感じる政治家や官僚によるその解体や権限 縮小の試みに直面してきた。とくに「警察からの組織的かつ徹底的な反発を受け，捏 造に近い強引な容疑で委員長, 副委員長が逮捕される事態」（114頁）に追い込まれ たが，公益のために判断しない，という法理にもとづき検事総長が判断を回避すると いう極めて政治的な判断によってその存続が確保されたことが明らかにされる。

司法化の進展が進むこ机ら諸国に対して，司法の政治関与が顕著ではない「司法 の自制」および「司法の沈黙」にある国として，マレーシアとミャンマーが取り上げ られる。マレーシアについて, 第 5 章「自由の守護者か, 権力の擁護者か：マレーシ アにおける政治的自由と裁判所」（鈴木綾女）においては，主要民族を代表する政党 が連合する国民戦線による長期政権と司法の関係が分析される。1980年代に裁判所 は政治には介入しないという従来の態度をあらため, 自然的正義や公共の利益という 原理を応用して, 行政命令の無効, 差止命令を出すようになったが, 行政は「憲法改 正や最高裁判所裁判官の罷免を通じて，司法に対する行政の優位を確立」した（137

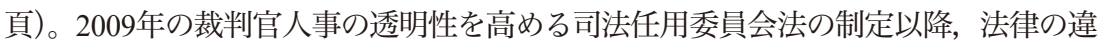
憲判決が出されたが，平和的集会法についての2014年の合憲判決以降，積極主義は 再び封じ込められた。筆者は, マレーシア司法の根強い保守主義は, 行政による裁判 官人事への介入によって引きこされていると分析する（137頁)。他方，第 6 章「ミャ ンマーにおける政治と司法：憲法裁の停滞と民主化の行方」(中西嘉宏) は，軍政下 に制定された2008年憲法によって新設された憲法裁判所には，軍に都合のよい政治 秩序の維持が期待されたが，2015年の総選挙で当時の軍に近い政権与党が惨敗して 以降，休眠状態にある。「そもそも司法に対する信頼が低く，積極的な憲法裁の政治 が行われているわけではないから，現状については司法の沈黙とみなした方がよいだ ろう」と結論する (158頁)。

このほか，東南アジア以外では，第 7 章「インドにおける政治の司法化と司法の独 立：コレージアム体制と第99次憲法改正」(上田知亮)，第 8 章「エジプトの司法と 
$\ulcorner 1$ 月25日革命」：移行期における司法の政治化（ダルウィッシュ・ホサム）」, 第 9 章「ロシアにおける憲法監督審制度と政治の「司法化」：憲法裁判所の事例を中心と して」(河原祐馬)，第10章「韓国における司法部の党派性の喪失と回復：民主化以 後の行政部の司法統制」(木村幹) による分析が行われる。

以上のような東南アジアおよびその他の国々の事例の検討を通じて，本書は，「判 事の人事」と「司法府を取り巻く政治状況」の 2 つの要因が司法化に影響を与える, と結論する。前者は，「誰が判事を任用するのか，誰が判事に任用されるのか」とい う点であり，具体的には，判事の任用における執政府や立法府の関与の度合い，任命 された者が任命権者の政治力にどれだけ依存したか，判事の出自，判事の任期が重 要であるとする。後者については，司法機関か政治へのチェックに積極的になるかど うかは，政治勢力の分散的多元的配置状況に左右され，「政治アクターが分散的多元 的であるほうが，司法化は活発になりやすい」(271頁) とする。

本書は，「政治の司法化」という少なくとも東南アジアでは新たな現象の解明に取 り組んだこと，そして，民主化の進展度や政治状況の異なる多様な国をひとつの議論 の组上にのせて論じたところに高い価值がある。しかしながら，それゆえに「司法化」 の概念を広く捉えており，その結果，枠組みをさらに精緻化すべき余地を残している ようにみえる。たとえば，本書で用いられる「司法政治」など類似する概念と司法化 の関係も示してほしかったところである。

また，本書において論じられているように，司法化の議論は，立憲主義と民主主義 との関係，法の支配と民主主義との関係という政治学，法律学における根本的な問題 と密接に関係している。これらの問題への接近は司法化論の魅力であると同時に，そ の迷宮に迷い込む危険性もあるように思う。

法律学など他分野の研究成果をいかに取り込んでいくかも今後の検討課題であろ う。本書でもすでに憲法学などの議論が参照されているが，たとえば，「司法の独立」 は法律学において司法のあり方を考える上で中心的に論じられてき問題であり，その ことは歴史的にみて司法がいかに外部の干渉を受けてきたかの証左でもある。本書が 結論として「判事の任用」のあり方に着目する点とも親和性をもつ。ただし，何をも って司法が独立であるとされるかは一義的には定められないのであって，法律学が明 確な回答を提供するわけではない。たとえば，司法の独立という観点からは司法は世 論に惑わされずに法を適用しなければならないが，同時に世論をまったく無視した司 法も同様に批判され得るのである。また，規範的な法律学においては，権威主義政治 体制における憲法や司法の問題は，外形的立憲主義や「司法の独立」が満たされな い事例としてむしろ中心的な議論から遠ざけられていた面がある。そうした空隙を埋 める上でも, 政治学としての司法化研究の優位性が少なくないことは本書でも示され 
ている通りである。

司法化と民主化との関係に焦点をあてるという本書の狙いから，主として取り上げ られている事例が，污職事件や選挙結果をめぐる争いなど，いわば裁判所がいずれ かの政治勢力に軍配を上げることを求められる事例に比重がおかれ，立憲主義の中核 をなす人権保障についての考察が相対的に少なくなつていることは物足りないと感じ られるかもしれない。司法化論に先鞭をつけた米国連邦最高裁判所の分析など先進 民主主義国を対象とする司法化の議論では，たとえば中絶や同性婚など国民の間で意 見が分かれる政策選択・価值判断の問題について司法が決定を下すことの問題性に も目が向けられているからである。フィリピンの経済政策をめぐる違憲判断の事例が 示すように, 東南アジア諸国の憲法のなかには人権条項だけでなく, 経済社会政策, ナショナリズム，イスラームなどの宗教，言語，さまざまな政策・価值に関する規定 が盛り込まれていて，司法の場に同じような政策・価值をめぐる対立などが持ち込ま れる基盤がすでに備わっている。

本書は，東南アジア諸国をはじめとする新興民主主義諸国の司法化を取り上げた先 駆的な業績である。本書は東南アジアを中心に各国・地域をフィールドとして活躍す る第一線の政治学者を執筆陣とし，司法の影響をめぐる政治過程の丁寧な記述，制 度の変化，裁判官のプロフィールなどに関する詳細なデータによって各国における司 法化の現状が鮮明に描かれている。東南アジアの多くの国で政策形成過程や政治過 程における司法機関の関与が顕著となりつつある現代において，司法化の分析は東南 アジア政治の理解のための不可欠の要素となつており, 本書が今後の研究の起点とな ることは間違いないだろう。

（連絡先：shinya_imaizumi@ide.go.jp） 